\title{
PELATIHAN PEMBUATAN DOKUMEN PROSEDUR OPERSIONAL BAKU PADA UD. GALARASA
}

\author{
Tegar Heru Susilo \\ Valentinus Roby Hananto \\ Yoppy Mirza Maulana \\ Dosen Institut Bisnis dan Informatika Stikom Surabaya
}

\begin{abstract}
UD. Galarasa is a home industry engaged in the production of snacks with its main product, "Kacang Aneh". The company's vision is to provide healthy snack products to be consumed by the public. Healthy that is correspond to the Minister of Health standards through P-IRT certification, and halal standards that is correspond to LPPOM MUI through Halal certifications. Healthy and halal certification process can be easily done if the company has standard operating procedure (SOP). Activities used in this IbM are create training modules, provide training, and gives assignments in accordance with the needs of the document and business processes. This training is able to change the behavior of individuals and organizations process refers to food quality and safety, and is able to improve individual insights of modern corporate management in accordance with the quality management system.

Keywords: small and medium enterprise, standard operating procedures, quality management system, food safety, halal, P-IRT, certification
\end{abstract}

\section{ABSTRAKSI}

UD. Galarasa adalah industri rumahan yang bergerak di bidang produksi makanan ringan dengan produk "Kacang Aneh". Perusahaan ini mempunyai visi menjadi penyedia produk makanan ringan yang sehat untuk dikonsumsi oleh masyarakat. Sehat dengan mengacu pada standar menteri kesehatan melalui sertifikasi P-IRT, dan Halal dengan mengacu pada standar LPPOM MUI melalui setifikasi halal. Proses sertifikasi sehat dan halal dapat dengan mudah dilakukan jika perusahaan mempunyai standard operating procedure (SOP). Metode yang digunakan dalam IbM ini adalah dengan membuat modul pelatihan, memberikan pelatihan, dan memberikan penugasan sesuai dengan kebutuhan dokumen dan proses bisnis perusahaan. Pelatihan dan penugasan ini mampu mengubah proses dan perilaku individu dan organisasi mengacu pada mutu dan keamanan pangan, serta meningkatkan wawasan individu tentang pengelolaan perusahaan secara modern sesuai dengan sistem manajemen mutu.

Kata kunci: usaha kecil dan menengah, prosedur operasional baku, sistem manajemen mutu, keamanan pangan, halal, P-IRT, sertifikasi

\section{PENDAHULUAN}

UD. Galarasa adalah industri rumahan yang bergerak di bidang produksi makanan ringan dengan produk "Kacang Aneh". Didirikan tahun 1998, perusahaan ini mempunyai visi menjadi penyedia produk makanan ringan yang sehat untuk dikonsumsi oleh masyarakat. Oleh karena itu, semua bahan baku, serta setiap lini dalam proses produksi dan berbagai kebijakannya, harus dipilih, dibuat dan dilakukan dengan mengacu pada kualitas "sehat".

Tanggung jawab perusahaan pengelola makanan tentang pangan yang diedarkan adalah keamanan pangan terhadap kesehatan orang lain yang mengkonsumsi pangan tersebut (Pemerintah RI, 1996). Untuk menjamin hal ini, setiap perusahaan pengelola makanan harus mendapatkan sertifikat layak produksi berupa nomor pangan industri rumah tangga (P-IRT). Materi P-IRT, salah satunya terkait dengan standar sanitasi dan cara produksi pangan yang baik untuk industri rumah tangga. Sedangkan proses dalam sertifikasinya, salah satunya terkait dengan pemeriksaan sarana produksi, dan proses produksi sesuai dengan standar sanitasi (Kepala Badan Pengawas Obat dan Makanan RI, 2012).

Selain sehat, ada pengaruh positif yang signifikan terhadap pemilihan produk makanan kemasan berlabel halal, oleh masyarakat (Fatkhurohmah, 2015). Untuk mendapatkan label halal, produk makanan harus melewati serangkaian prosedur sertifikasi halal dari LPPOM MUI (MUI, 2016). Kedua mutu ini, halal dan sehat, merupakan mutu standar untuk mencapai tingkat kelayakan konsumsi produk makanan. 
Awareness perusahaan tentang kedua mutu standar ini sudah baik. Namun, tantangan muncul ketika terjadi proses sertifikasi sehat dan halal. Proses sertifikasi sehat dan halal dapat dengan mudah dilakukan jika perusahaan mempunyai prosedur operasional baku atau yang umum disebut standard operating procedure (SOP). Hal ini seperti yang tertuang dalam dokumen HAS 23000 tentang persyaratan sertifikasi halal pada bagian kriteria sistem jaminan halal tentang prosedur tertulis dan kemampuan telusur (MUI, 2016). Prosedur tertulis dalam hal ini adalah seluruh kegiatan atau aktifitas dalam produksi yang disesuaikan dengan proses bisnis perusahaan yang menjamin semua bahan, produk, dan fasilitas produksi yang digunakan memenuhi kriteria sertifikasi halal.

Saat ini perusahaan tidak memiliki kapasitas, baik dari segi pengetahuan maupun sumber daya, untuk membuat prosedur operasional baku. Melihat kebutuhan tersebut, dalam kegiatan pengabdian masyarakat kali ini, diusulkan pelatihan pembuatan dokumen prosedur operasional baku kepada mitra yaitu UD. Galarasa. Dengan pelatihan ini, diharapkan pihak perusahaan dapat membuat prosedur operasional baku sesuai dengan kebutuhan perusahaan terhadap pencapaian mutu sehat dan halal.

\section{TINJAUAN PUSTAKA}

\section{Usaha Kecil dan Menengah (UKM)}

Usaha Kecil dan Menengah (selanjutnya disebut sebagai UKM) dikatakan sebagai tiang ekonomi rakyat. Dengan tingkat penyerapan tenaga kerja yang cukup, hal ini mampu mengurangi angka pengangguran dan kemiskinan (Adiningsih, 2004). Berbagai upaya untuk meningkatkan kuantitas dan kualitas UKM menjadi prioritas layanan bagi Kementrian Koperasi dan UKM, bahkan dukungan dari pihak swasta. Dan penerapan teknologi informasi dan komunikasi (TIK) menjadi salah satu upaya bersama antara pemerintah dan swasta untuk meningkatkan kualitas UKM di Indonesia.

Usaha kecil dan menengah merupakan salah satu kekuatan pendorong terdepan dalam pembangunan ekonomi. Gerak sektor UKM amat vital untuk menciptakan pertumbuhan dan lapangan pekerjaan. UKM cukup fleksibel dan dapat dengan mudah beradaptasidengan pasang surut dan arah permintaan pasar. Mereka juga menciptakan lapangan pekerjaan lebih cepat dibandingkan sektor usaha lainnya, dan mereka juga cukup terdiversifikasi dan memberikan kontribusi penting dalam ekspor dan perdagangan (Bank Dunia, 2010).

Di Indonesia, sumber penghidupan amat bergantung pada sektor UKM. Kebanyakan usaha kecil ini terkonsentrasi pada sektor perdagangan, pangan, olahan pangan, tekstil dan garmen, kayu dan produk kayu, seta produksi mineral non-logam. Mereka bergerak dalam kondisi yang amat kompetitif dan ketidakpastian, juga amat dipengaruhi oleh situasi ekonomi makro. Lingkungan usaha yang buruk lebih banyak merugikan UKM daripada usaha besar.

UKM dibagi kedalam tiga kategori, yaitu (1) Usaha Mikro, (2) Usaha Kecil, dan (3) Usaha Menengah. Pembagian ini disesuaikan dengan kriteria berupa kekayaan dan omset yang dihasilkan. Usaha Kecil sendiri merupakan kegiatan ekonomi rakyat yang berskala kecil dengan kriteria sebagai berikut (Pemerintah Republik Indonesia, 1995):

1. Memiliki kekayaan bersih paling banyak Rp. 200.000.000,- (dua ratus juta rupiah), tidak termasuk tanah dan bangunan tempat usaha; atau

2. Memiliki hasil penjualan tahunan paling banyak Rp. 1.000.000.000,- (satu milyar rupiah);

3. Milik Warga Negara Indonesia (WNI);

4. Berdiri sendiri, bukan merupakan anak perusahaan atau cabang perusahaan yang dimiliki, dikuasai, atau berafiliasi baik langsung maupun tidak langsung dengan Usaha Menengah atau Usaha Besar;

5. Berbentuk badan usaha perseorangan, badan usaha yang tidak berbadan hukum, atau badan usaha yang berbadan hukum, termasuk koperasi.

Pada UU yang sama, diatur juga mengenai iklim usaha sesuai dengan peraturan perundang-undangan yang meliputi salah satunya adalah informasi. Dukungan pemerintah terhadap informasi ini berbentuk bank data dan jaringan informasi bisnis, serta pengadaan dan penyebaran informasi mengenai pasar, teknologi, desain, dan mutu. Selain iklim usaha, diatur juga mengenai pembinaan dan pengembangan yang salah satunya terkait dengan teknologi. Pembinaan ini dilakukan dengan cara salah satunya adalah peningkatan kemampuan di bidang teknologi.

\section{SISTEM MANAJEMEN MUTU}

Di Indonesia, kualitas sebuah produk didasarkan pada merek dan harga, sedangkan 
harga menjadi faktor utama dalam menentukan pembelian suatu produk. Karakteristik tersebut menggambarkan output atau hasil dari suatu proses tanpa memperhatikan produk tersebut selama proses produksinya. Sehingga tidaklah heran jika menimbulkan salah persepsi terhadap mutu produk tersebut, seperti barang dengan harga tinggi identik dengan mutu yang tinggi. Sedangkan harga adalah fungsi dari cost, profit margin, dan kekuatan pasar. Menurut ISO 9000:2000, mutu didefinisikan sebagai:

"derajat/tingkat karakteristik yang melekat pada produk yang mencukupi persyaratan /keinginan"

Maksud derajat/tingkat disini berarti selalu ada peningkatan setiap saat. Sedangkan karakteristik berarti hal-hal yang dimiliki produk, dalam bentuk:

1. Karakteristik fisik (elektrikal, mekanikal, biologikal), seperti handphone, mobil, dan rumah.

2. Karakteristik perilaku (kejujuan, kesopanan), seperti rumah sakit dan perbankan.

3. Karakteristik sensori (bau, rasa), seperti minuman dan makanan.

Ada dua arti mutu yang sangat penting bagi manajer, yaitu:

1. Keistimewaan produk: semakin baik keistimewaannya, semakin tinggi mutunya. Hal ini berdampak pada penjualan.

2. Bebas defisiensi: semakin sedikit defisiensi, semakin baik mutunya. Hal ini berdampak pada biaya.

Total Quality Management (TQM) mengisyaratkan kepuasan karyawan yang tercermin dari kualitas pelayanan internal. Kualitas pelayanan internal ini tercermin dalam lingkungan kerja yang kondusif (lewat pemberdayaan, delegasi wewenang, saling percaya, komunikasi yang efektef, dan sebagainya) dan penerapan total human reward. Hal ini akan mendorong tumbuhnya loyalitas karyawan. Selanjutnya, loyalitas karyawan akan mengarah kepada peningkatan produktifitas. Produktifitas karyawan akan mendorong terciptanya nilai pelayanan eksternal, yang kemudian menentukan kepuasan pelanggan eksternal. TQM merupakan dasar dari manajemen dalam menerapkan Sistem Manajemen Mutu yang telah distandarkan oleh lembaga internasional ISO, yaitu ISO IEC 9001:2008. Ada tujuh prinsip manajemen mutu, antara lain:1. Fokus pada pelanggan, 2. Kepemimpinan. 3. Keterlibatan orang, 4.
Pendekatan proses. 5. Perbaikan berkesinambungan. 6. Pembuatan keputusan berbasis bukti. 7. Manajemen hubungan ISO mengadopsi pendekatan berbasis proses ketika membangun, implementasi dan meningkatkan efektifitas sistem manajemen mutu, untuk meningkatkan kepuasan pelanggan dengan cara memenuhi kebutuhan mereka. Agar perusahaan dapat berfungsi secara efektif, perusahaan harus menentukan dan mengelola berbagai macam aktifitas. Aktifitas yang membutuhkan sumber daya, dan dikelola untuk mengubah input menjadi output, dapat disebut sebagai proses. Pada umumnya, output dari sebuah proses menjadi input bagi proses lainnya. Keuntungan pendekatan proses adalah ongoing control yang menyediakan keterkaitan antara proses tunggal dengan sistem (kumpulan proses), begitu juga kombinasi dan interaksinya. Inilah yang dikenal dgn "Pendekatan Proses". Model pendekatan proses dapat dilihat pada Gambar 1.

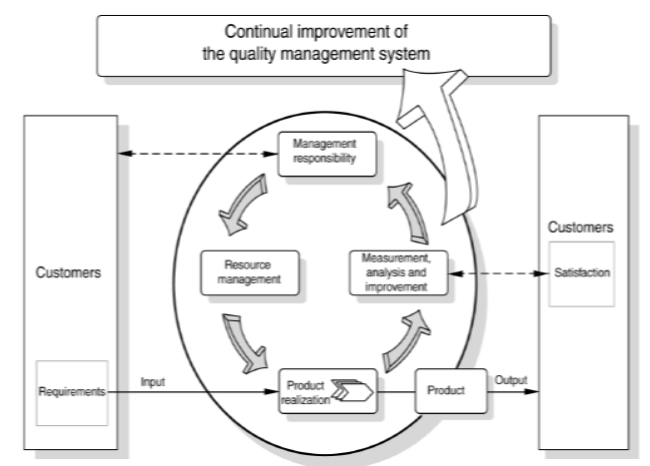

Gambar 1. Sistem Manajemen Mutu (sumber: ISO 9001:2008)

\section{Keamanan Pangan}

Sistem manajemen keamanan pangan menggunakan ISO 22000:2009 yang sudah diadopsi oleh lembaga Standarisasi Nasional Indonesia (SNI) menjadi SNI ISO 22000:2009. Standar ini menggabungkan prinsip-prinsip sistem analisis bahaya dan pengendalian titik control (Hazard Analysis and Critical Control Point - HACCP) dan langkah-langkah penerapan yang dikembangkan oleh lembaga CAC (Codex Alimentarius Commission). Standar ini mengkombinasikan rencana HACCP dengan program persyaratan dasar (PPD). HACCP dapat membantu mengorganisasikan pengetahuan yang diperlukan untuk menetapkan tindakan pengendalian yang efektif. HACCP mensyaratkan bahwa semua bahaya yang mungkin timbul dalam rantai pangan, termasuk 
bahaya yang terkait dengan proses dan fasilitas yang digunakan, dapat diidentifikasi dan dikaji.

HACCP dapat diterapkan di industri pangan yang telah menjalankan proses pengolahan dengan cara produksi makanan yang baik atau good manufacturing practice (GMP) dan sanitation standard operating procedure (SSOP) yang sesuai. GMP merupakan pedoman cara produksi makanan yang bertujuan agar produsen memenuhi persyaratan-persyaratan yang telah ditentukan untuk menghasilkan produk bermutu sesuai tuntutan konsumen. Di Indonesia, pedoman pelaksanaan GMP dalam industri ditetapkan berdasarkan SK Menteri Kesehatan RI No. 23/MENKES/SK/I/1978 tanggal 24 Januari 1978 tentang Pedoman Cara Produksi yang Baik untuk Makanan.

SSOP merupakan prosedur yang dibuat untuk membantu industri pangan dalam mengembangkan dan menerapkan kondisi sanitasi, pengawasan serta melakukan monitoring terhadap penerapan sanitasi (Thaheer, 2003). Menurut FDA (1996), SSOP adalah prosedur tertulis yang dibuat dan diterapkan untuk mencegah kontaminasi silang atau pencemaran produk. SSOP dibagi kedalam delapan aspek, yaitu keamanan air, kebersihan permukaan benda yang bersentuhan dengan pangan, pencegahan kontaminasi silang, sanitasi karyawan, pencemaran, komponen toksik, kesehatan karyawan, dan pengendalian hama.

\section{Standard Operating Procedure (SOP)}

Pada dasarnya, SOP adalah suatu kakas bantu pengatur, yang mengatur tahapan suatu proses kerja atau prosedur kerja tertentu. Oleh karena prosedur kerja yang dimaksud bersifat tetap, rutin, dan tidak berubah-ubah, prosedur kerja tersebut dibakukan menjadi dokumen tertulis yang disebut sebagai SOP. Prosedur kerja tersebut haruslah mudah dipahami dan dapat di implementasikan dengan baik dan konsisten oleh pelaku. Menurut Permenpan no. 35 tahun 2012, SOP merupakan serangkaian instruksi tertulis yang dibakukan mengenai berbagai proses penyelenggaraan aktivitas organisasi, bagaimana dan kapan harus dilakukan, dimana dan oleh siapa dilakukan. Implementasi SOP yang baik akan menunjukkan konsistensi hasil kerja, hasil produk dan proses pelayanan seluruhnya dengan mengacu kepada kemudahan, pelayanan dan pengaturan yang seimbang.

Sebagai kakas bantu, SOP mempunyai peran strategis dalam organisasi untuk meningkatkan efisiensi dan efektifitas dalam setiap proses kerja organisasi. Selain itu, SOP juga menjadi panduan dalam pengelolaan kegagalan dan resiko yang muncul. Pengelolaan ini didukung oleh sistem pengawasan yang terintegrasi kedalam proses kerja organisasi, dalam hal ini berupa quality assurance (penjaminan mutu). Selain peran strategis, SOP juga mempunyai manfaat antara lain:

1. Sebagai standarisasi dalam menyelesaikan pekerjaan yang menjadi tugasnya.

2. Mengurangi tingkat kesalahan dan kelalaian yang mungkin dilakukan oleh seseorang dalam melaksanakan tugasnya.

3. Meningkatkan efisiensi dan efektivitas pelaksanaan tugas dan tanggung jawab individual dan organisasi secara keseluruhan.

4. Menciptakan ukuran standar kinerja yang akan memberikan cara konkrit untuk memperbaiki kinerja serta membantu mengevaluasi usaha yang telah dilakukan.

5. Menjamin konsistensi pelayanan kepada pelanggan, baik dari sisi mutu, waktu, dan prosedur.

6. Memberikan informasi mengenai kualifikasi kompetensi yang harus dikuasai oleh individu dalam melaksanakan tugasnya.

7. Menghindari tumpang tindih pelaksanaan tugas.

8. Membantu penelusuran terhadap kesalahankesalahan prosedural dalam memberikan pelayanan atau me-laksanakan tugas;

\section{METODE PELAKSANAAN}

Pengelolaan Pelatihan

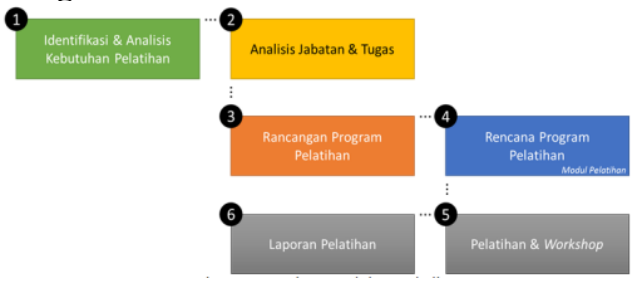

Gambar 2. Kerangka pengelolaan pelatihan

\section{Identifikasi dan Analisis Kebutuhan Pelatihan}

Tanggung jawab perusahaan pengelola makanan tentang pangan yang diedarkan adalah keamanan pangan terhadap kesehatan orang lain yang mengkonsumsi pangan tersebut (Pemerintah RI, 1996). Untuk menjamin hal ini, setiap perusahaan pengelola makanan harus mendapatkan sertifikat layak produksi berupa nomor pangan industri rumah tangga (P-IRT). 
Selain sehat, ada pengaruh positif yang signifikan terhadap pemilihan produk makanan kemasan berlabel halal, oleh masyarakat (Fatkhurohmah, 2015). Untuk mendapatkan label halal, produk makanan harus melewati serangkaian prosedur sertifikasi halal dari LPPOM MUI (MUI, 2016). Kedua mutu ini, halal dan sehat, merupakan mutu standar untuk mencapai tingkat kelayakan konsumsi produk makanan.

Awareness perusahaan tentang kedua mutu standar ini sudah baik. Namun, tantangan muncul ketika terjadi proses sertifikasi sehat dan halal. Proses sertifikasi sehat dan halal dapat dengan mudah dilakukan jika perusahaan mempunyai prosedur operasional baku atau yang umum disebut standard operating procedure (SOP). Hal ini seperti yang tertuang dalam dokumen HAS 23000 tentang persyaratan sertifikasi halal pada bagian kriteria sistem jaminan halal tentang prosedur tertulis dan kemampuan telusur (MUI, 2016). Prosedur tertulis dalam hal ini adalah seluruh kegiatan atau aktifitas dalam produksi yang disesuaikan dengan proses bisnis perusahaan yang menjamin semua bahan, produk, dan fasilitas produksi yang digunakan memenuhi kriteria sertifikasi halal.

\section{ANALISIS JABATAN DAN TUGAS}

Penyusunan SOP merupakan tanggung jawab dari pimpinan perusahaan, namun tidak menutup kemungkinan tanggung jawab ini dapat didelegasikan. Pendelegasian dilakukan kepada karyawan yang memahami proses bisnis perusahaan dan memiliki kemampuan bahasa yang baik. Proses bisnis ini melingkupi standar mutu dan keamanan pangan yaitu pada setiap mata rantai proses produksi dimulai dari penerimaan bahan (baku dan pendukung), proses pengolahan (produksi), dan produk akhir (pengepakan sampai pada pengiriman).

\section{RANCANGAN DAN RENCANA PROGRAM PELATIHAN}

1. Isi atau muatan materi pelatihan

Materi yang akan diberikan selama pelatihan adalah mengenai sistem manajemen mutu dan keamanan pangan, serta bagaimana menyusun dokumen SOP. Selama pelatihan, peserta pelatihan akan diberi tugas terkait penyusunan dokumen SOP dan akan diulas bersama-sama.

2. Metode dan media pelatihan
Pelatihan diberikan dalam bentuk ceramah, diskusi, dan penugasan dengan mentor (pembimbing/fasilitator) dan asisten mentor adalah para peneliti dengan latar belakang pekerjaan sebagai Dosen. Peserta pelatihan adalah pimpinan atau karyawan (yang didelegasi) perusahaan yang memahami mata rantai proses produksi dimulai dari penerimaan bahan (baku dan pendukung), proses pengolahan (produksi), dan produk akhir (pengepakan sampai pada pengiriman). Sedangkan untuk membantu dalam penyampaian materi pelatihan, dibutuhkan:

1) Ruang dengan kapasitas sekitar 6-8 orang.

2) Proyektor beserta layar proyektor, perangkat PC, dan papan tulis beserta alat tulisnya (opsional)

3) Modul pelatihan (sebagai bahan ajar), serta alat tulis selama pelatihan bagi mentor dan peserta pelatihan.

3. Kebutuhan waktu pelatihan

Dengan melihat muatan materi pelatihan, maka pelatihan akan diadakan selama 10 jam yang terdiri dari penyampaian materi, penugasan, dan ulasan.

\section{MODUL PELATIHAN}

Modul merupakan salah satu bentuk bahan ajar yang dikemas secara utuh dan sistematis. Didalamnya memuat seperangkat pengalaman belajar yang terencana dan didesain untuk membantu pesera didik menguasai tujuan belajar yang spesifik (Rahdiyanta, 2014). Sebagai bahan ajar, modul membantu pengajar dalam melaksanakan pembelajaran, pegangan dalam menentukan metode pembelajaran dan menjamin keberlangsungan materi pembelajaran. Bagi peserta didik, modul dapat dipakai sebagai panduan dalam pembelajaran (termasuk dalam belajar mandiri).

Modul sebagai bahan ajar, menurut Thiagarajan (Thiagarajan dalam Tiarani (Tiarani, 2011)), dapat dikembangkan menggunakan model Four-D Model yang meliputi tahap pendefinisian (define), perancangan (design), pengembangan (develop), dan pendiseminasian (disseminate). Dalam model ini, tahap pendefinisian diawali dengan mengkaji standar kompetensi dan kompetensi dasar yang hendak dicapai yang telah ditetapkan dalam pembelajaran dan analisis kebutuhan peserta didik. Tahap perancangan adalah tahap merancang prototype (purwarupa) bahan ajar. 
Pada tahap pengembangan, dibuat naskah bahan ajarnya sehingga menghasilkan apa yang disebut "desain". Desain-desain tersebut biasanya kemudian diserahkan kepada pakar yang memiliki spesialisasi di bidangnya untuk di-review. Tahap yang terakhir adalah tahap diseminasi. Pada tahap ini naskah seperangkat bahan ajar yang sudah di-review diimplementasikan dalam proses pembelajaran.

\section{PELAKSANAAN PELATIHAN}

Pelatihan dilaksanakan sesuai dengan rancangan dan rencana program pelatihan, dengan hasil sebagai berikut:

1. Target perusahaan yang dilatih adalah 2 perusahaan, yaitu UD. Galarasa dan Janna Jaya.

2. Peserta pelatihan:

1) Dari UD. Galarasa: 3 orang (1 owner, 2 karyawan)

2) Dari Janna Jaya: 2 orang (1 owner, 1 karyawan)

3. Lokasi pelatihan: Masjid At-Taqwa Ds. Windurejo, Kec. Kutorejo

Pelatihan dilaksanakan didalam ruang kelas yang selama ini belum terpakai. Sehingga dengan adanya pelatihan ini, ruang tersebut dapat dimanfaatkan dan mampu memberikan pemasukan bagi masjid. Ruang kelas dinilai telah memenuhi persyaratan dalam rancangan pelatihan.

4. Waktu penyelenggaraan:

Pelatihan dilaksanakan dalam 2 pertemuan dengan waktu 5 jam per pertemuan, total 10 jam sesuai dengan rancangan pelatihan. Pelatihan dilaksanakan pada hari Sabtu/Minggu untuk meminimalkan tingkat ketidakhadiran peserta.

1) 28 Agustus 2016, 10.00 s.d 15.00

2) 3 September, 10.00 s.d 15.00

5. Bahan pelatihan: modul pelatihan dan slide presentasi (cetak)

6. Dokumentasi:

1) Sebelum pelatihan, tim pelatihan membuat undangan bagi setiap perusahaan untuk mengirimkan maksimal 2 orang perwakilan perusahaan untuk mengikuti pelatihan sesuai dengan jadwal yang telah direncanakan.

2) Setiap pertemuan pelatihan, setiap peserta dan mentor dan asisten mentor harus mengisi daftar kehadiran.

3) Setiap pertemuan pelatihan dan berbagai kegiatan pelatihan akan didokumentasikan dalam bentuk foto.
7. Pelaksanaan pelatihan: dalam rencana kegiatan pengabdian masyarakat, muncul aktifitas workshop. Dalam pelaksanaannya, workshop ditiadakan dan digantikan oleh penugasan. Penugasan diberikan oleh mentor sesuai dengan materi dan harus dijawab sesuai dengan karakter masingmasing perusahaan. Penugasan diberikan ketika terdapat materi yang memang perlu (penting) bagi perusahaan untuk diidentifikasi. Selama penugasan, peserta didampingi oleh asisten mentor dalam mengidentifikasi dan menyusun SOP.

\section{PEMBAHASAN}

Pelatihan yang sudah dilaksanakan mempunyai dampak yang besar bagi perubahan baik proses maupun perilaku, tidak hanya manusianya, tetapi juga organisasinya. Hal ini dapat terlihat dari hasil yang dicapai selama pelatihan.

\section{CAPAIAN}

1. Peserta mampu merancang visi-misi dan tujuan perusahaan, disesuaikan dengan manajemen mutu dan keamanan pangan.

2. Peserta mampu mengidentifikasi seluruh rantai proses bisnis inti terkait dengan manajemen mutu dan keamanan pangan.

3. Peserta mampu membuat dokumen SOP, instruksi kerja, dan rekaman kerja sesuai dengan rantai proses yang telah diidentifikasi.

4. Peserta pro-aktif dalam berbagai aktifitas, terutama ketika penugasan pembuatan SOP.

\section{Faktor Pendukung}

1. Pendanaan yang didukung sepenuhnya oleh Institut Bisnis dan Informatika Stikom Surabaya yang terwadahi dalam program Pengabdian Masyarakat.

2. Respon positif dari pihak perusahaan, yaitu UD. Galarasa dan Janna Jaya, sebagai bentuk partisipasi mereka dan keinginan mereka untuk dapat tumbuh dan berkembang menjadi perusahaan yang dikelola secara modern.

3. Penyediaan fasilitas, sarana, dan prasarana oleh pihak peserta dan pihak Takmir Masjid At-Taqwa. Sebagai informasi tambahan, dalam pelatihan penyusunan dokumen, peserta membawa laptop (notebook) sendiri.

4. Kompetensi mentor dan asisten mentor sangat membantu mulai dari perancangan 
modul sampai dengan penyampaian materi serta asistensi selama penugasan.

\section{Faktor Penghambat}

1. Penyusunan jadwal pelatihan yang harus disesuaikan dengan jadwal mentor, jadwal peserta, dan jadwal pemakaian lokasi. Pelatihan direncanakan dimulai sekitar minggu ketiga Agustus, tetapi karena beberapa hal yang terjadi diluar kuasa tim, maka pelatihan dilaksanakan mulai minggu keempat Agustus. Hal ini berdampak pada perubahan peminjaman lokasi. Lokasi pelatihan berada di daerah Kutorejo untuk efektifitas dan efisiensi selama pelatihan.

2. Tingkat keterlambatan masih tinggi, namun peserta tetap konsisten mengikuti pelatihan. Dampak dari keterlambatan ini adalah tertundanya pelatihan. Namun, karena kompetensi mentor dan asisten mentor, dengan waktu yang ada, semua materi dapat disampaikan.

3. Kurangnya kemampuan peserta dalam mengoperasikan laptop (notebook), terlebih lagi dalam mengoperasikan aplikasi pengolah dokumen (Ms. Word).

4. Materi yang diberikan bersifat umum, namun dalam penugasan bersifat khusus. Artinya ketika menjawab tugas-tugas yang diberikan oleh mentor, peserta harus menjawab sesuai karakter perusahaan (visimisi, tujuan, proses bisnis, sampai dokumen SOP). Selama penugasan, ada pendampingan dan bimbingan. Pendampingan ini menjadi tidak efektif jika ada banyak perusahaan yang terlibat selama pelatihan.

\section{Evaluasi}

Pelatihan terlaksana sesuai dengan rancangan dan rencana pelatihan, tentunya dengan sedikit perubahan karena ada kondisi diluar kuasa tim. Perubahan yang terjadi tetap dapat di-handle dengan baik. Selama pelatihan berlangsung, terjadi perubahan pada proses dan sikap, tidak hanya individu, tetapi juga pada tingkat organisasi. Hal ini dapat dilihat pada hasil capaian pelatihan, dimana peserta mampu mengidentifikasi visi-misi dan tujuan perusahaan serta proses bisnis inti perusahaan. Kemampuan ini semua didasari oleh pemikiran setiap peserta mengenai manajemen mutu dan keamanan pangan. Sehingga penyusunan SOP, instruksi kerja, dan rekaman kerja merupakan hasil sintesa peserta pelatihan dalam menghubungkan proses bisnis dan keamanan pangan. Selain itu, proses pendampingan selama penugasan mampu membuka wawasan mereka terhadap bagaimana pengelolaan perusahaan dengan cara modern mengacu pada sistem manajemen mutu. Hal ini dapat dilihat dari hasil identifikasi visi-misi, tujuan, dan proses bisnis yang dilakukan oleh peserta.

Antusiasme yang tinggi dari peserta pelatihan dalam hal manajemen mutu dan keamanan pangan, memberikan keyakinan tersendiri bahwa masih banyak UMKM yang memerlukan pelatihan sejenis. Pemilik perusahaan pun, merasakan kebermanfaatan yang luar biasa dari pelatihan ini dan memungkinkan jika dibentuk pelatihan lanjutan yang lebih spesifik berbicara tentang analisis proses bisnis sampai terbentuk SOP, instruksi kerja, dan rekaman kerja yang dapat langsung diimplementasikan oleh perusahaan.

\section{KESIMPULAN DAN SARAN Kesimpulan}

1. Dengan pelatihan SOP, terjadi perubahan dalam proses dan sikap, tidak hanya pada individu, tetapi juga di tingkat organisasi. Hal ini didukung oleh capaian pelatihan dimana individu telah mampu mengidentifikasi visi-misi dan tujuan perusahaan serta proses bisnis inti, yang semuanya mengacu pada sistem manajemen mutu dan keamanan pangan.

2. Dengan pelatihan SOP, terjadi peningkatan wawasan individu terhadap bagaimana mengelola perusahaan dengan cara modern mengacu pada sistem manajemen mutu.

\section{Saran}

Pelatihan SOP dapat ditindaklanjuti dengan membentuk pelatihan untuk membantu perusahaan dalam menganalisis proses bisnis perusahaan. Usulan ini merupakan bagian dari kajian manajemen proses bisnis dimana perusahaan mampu mengidentifikasi dampak atau resiko atau biaya di setiap proses bisnis. Ujung dari pengelolaan ini adalah perubahan proses bisnis berupa otomasi, simplifikasi, eliminasi, dan/atau integrasi.

\section{Daftar pustaka}

1. Fatkhurohmah. (2015). Pengaruh Pemahaman Label Halal dan Faktor Sosial Terhadap Niat Membeli Produk Makanan Kemasan Berlabel Halal. Yogyakarta: Universitas Negeri Yogyakarta. 
2. Kepala Badan Pengawas Obat dan Makanan RI. (2012). Peraturan Kepala Badan Pengawas Obat dan Makanan RI no. HK.03.1.23.04.12.2205 tahun 2012 tentang Pedoman Pemberian Sertifikat Produksi Pangan Industri Rumah Tangga. Jakarta.

3. Menteri Kesehatan RI. (2003). Keputusan Menteri Kesehatan RI no. 715 tahun 2003 tentang Persyaratan Hygiene Sanitasi Jasaboga. Jakarta.

4. MUI. (2016, 3 18). Prosedur Sertifikasi Halal MUI. Diambil kembali dari LPPOM MUI: http://www.halalmui.com

5. Pemerintah RI. (1996). Undang-undang no. 7 tahun 1996 tentang Pangan. Jakarta. 